
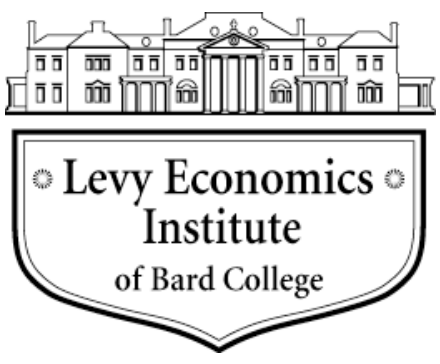

Working Paper No. 272

\title{
Functional Finance and Full Employment: Lessons from Lerner for Today?
}

by

\author{
Mathew Forstater \\ The Jerome Levy Economics Institute
}

July 1999

The Levy Economics Institute Working Paper Collection presents research in progress by Levy Institute scholars and conference participants. The purpose of the series is to disseminate ideas to and elicit comments from academics and professionals.

Levy Economics Institute of Bard College, founded in 1986, is a nonprofit, nonpartisan, independently funded research organization devoted to public service. Through scholarship and economic research it generates viable, effective public policy responses to important economic problems that profoundly affect the quality of life in the United States and abroad.

\author{
Levy Economics Institute \\ P.O. Box 5000 \\ Annandale-on-Hudson, NY 12504-5000 \\ http://www.levyinstitute.org
}

Copyright (C) Levy Economics Institute 1999-2013 All rights reserved

ISSN 1547-366X 


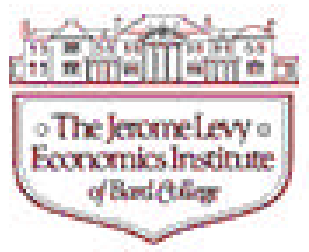

\title{
Working Paper No. 272
}

Functional Finance and Full Employment:

Lessons from Lerner for Today?

\author{
by \\ Mathew Forstater \\ The Jerome Levy Economics Institute
}

July 1999

The Asian Crisis, with the fallout in Latin America and the transition economies; the Russian default; continuing troubles in Japan; weaknesses in the structure of the new European EMU; volatility on Wall Street; deflationary pressures in the global economy: recent economic developments invite a reconsideration of some of our most deeply held beliefs concerning economic theory and public policy. Even within the hallowed halls of mainstream economics, voices of dissent can be heard. Paul Krugman, Joseph Stiglitz, and Jeffrey Sachs are among those whose recent proclamations indicate that we have entered a period in which orthodox views are being openly questioned, creating an atmosphere characterized by a crisis of confidence.

Such periods of impending crisis and open expressions of self-doubt, questioning our most deeply held beliefs about the way the world works, creates a climate in which the ideas of the great unorthodox thinkers of the past may be revisited. The work of those who in the past dedicated their lives to formulating solutions to the challenges of modern capitalist economies may contain lessons applicable to the contemporary situation. It is in this spirit that this paper revisits the early works of Abba Lerner, outlining fifteen such lessons regarding macroeconomic theory and policy, as fresh in the context of the current scene as they were some five decades ago when they were first formulated.

\section{Lesson \#1: Full employment, price stability, and a decent standard of living for all are fundamental macroeconomic goals, and it is the responsibility of the state to promote their attainment.}

Lerner rejected the positive/normative dichotomy in economics. His distinction between "objective" and "normative" was based not on whether one considers macroeconomic goals as part and parcel of their analysis, but whether one does so openly and honestly:

Objectivity turns out to be not the avoidance of concern with what is desired in a pure concentration on what $i s$, but merely the avoidance of smuggling in an advocacy of desired objectives without making it clear that this is being done or making it clear whose are the desires being considered $(1969,131)$.

Lerner (1941) likened laissez-faire to a refusal to take hold of the "economic steering wheel." Government must use its powers to "fill its two great responsibilities, the prevention of depression, and the maintenance of the value of money" $(1947,314)$.

Lerner's arguments for full employment are worth reviewing. First, "the economic gains from full employment are enormous" (1951, 31-32). The costs of unemployment are staggering. These include the permanent loss of output of goods and services, but also the social costs resulting from increased crime, illness, and other social problems.

Full employment increases efficiency. By removing the threat imposed on workers by the existence of a reserve army of unemployed, workers will feel more confident to move out of one job and into another. This often means a movement from a lower productivity job to a higher productivity job $(1951,32)$. 
Individual economic security is an even more important benefit than the increase in goods and services (1951, 33). Though this means foremost individual economic security for workers, government commitment to full employment has an important stabilizing impact on business confidence, derived from the awareness that the state is committed to maintaining aggregate demand $(1951,33)$.

A full-employment policy can weaken racial and other discrimination in hiring (1951,36). There are incentives in an economic system characterized by general unemployment for workers to seek ways of "tying up the jobs they have so they cannot be easily fired" $(1951,34)$. "The economic interest of a group of workers in protecting their scarce jobs against competition from outside," so often conducted through racial and other discrimination, would be significantly decreased with the elimination of job scarcity $(1951,36-37)$. In addition, employers, who have the opportunity to indulge their own racial and other prejudices in hiring when there is widespread unemployment, would no longer be able to do so in a full-employment economy $(1951,36)$. Full employment also helps to remove wage differentials, well-known to be highly related to race and gender (1951, $37)$.

Full employment is key to social stability (1951,37ff.). Without employment and income security, citizens are vulnerable to dangerous ideologies, scapegoating, and anti-democratic political movements.

Full employment and the maintenance of the value of the currency are the key initial prerequisites for a decent standard of living for all. To leave such matters to the market would be like driving a car without using the steering wheel. Fortunately, people do not drive their cars without using the steering wheel:

But are they as reasonable about other things as they are about the desirability of steering their automobiles?...Do they not allow their economic automobiles to bounce from depression to inflation in wide and uncontrolled arcs? Through their failure to steer away from unemployment and idle factories are they not just as guilty of public injury and insecurity as the mad motorists...? (Lerner, 1951, 4-5).

\section{Lesson \#2: Policies should be judged on their ability to achieve the goals for which they are designed and not on any notion of whether they are "sound" or otherwise comply with the dogmas of traditional economics.}

This, of course, is Lerner's functional finance (1943). The state has the ability to promote full employment and price stability and should use its powers to do so:

The central idea is that government fiscal policy, its spending and taxing, its borrowing and repayment of loans, its issue of new money and its withdrawal of money, shall all be undertaken with an eye only to the results of these actions on the economy and not to any established traditional doctrine about what is sound and what is unsound. This principle of judging only by effects has been applied in many other fields of human activity, where it is known as the method of science opposed to scholasticism. The principle of judging fiscal measures by the way they work or function in the economy we may call Functional

Finance ...Government should adjust its rates of expenditure and taxation such that total spending in the economy is neither more nor less than that which is sufficient to purchase the full employment level of output at current prices. If this means there is a deficit, greater borrowing, "printing money," etc., then these things in themselves are neither good nor bad, they are simply the means to the desired ends of full employment and price stability (1943, 354).

This principle is so simple, yet apparently so difficult to understand. If one supports balancing the budget as the proper means to achieving some economic goal, this is entirely consistent with the principle of functional finance. It is not the balanced budget that is "sacred," it is simply a means to the ends that are desired. They should thus agree, in principle, that if some other relation between government expenditure and tax receipts were the best means to attaining those ends, the balanced budget should be abandoned and those other means instituted. But if one promotes a balanced budget as an end in itself--as the "right" thing to do, it would be 
"irresponsible" to do otherwise--without regard to the potential effects and the sacrifice of macro goals, this is not consistent with the principle of functional finance. This is best referred to as dysfunctional finance .

If one is opposed to government borrowing, lending, taxing, spending, buying, or selling, it should be because such an action will cause unemployment, inflation, deflation, or some other undesirable macroeconomic outcome, or because it will hinder the abolition of these undesirable macroeconomic problems. But if any of those means promotes the desired macro goals or prevents undesirable macro problems, then they should be utilized for that purpose. There is nothing inherently "good" or "bad" about any particular relation between government expenditure and tax receipts. It all depends on the economic circumstances and on the results that such a relation will promote under those circumstances. If the amount of taxing, spending, borrowing, lending, buying, or selling "should conflict with the principles of 'sound finance' or of balancing the budget or of limiting the national debt, so much the worse for those principles" $(1951,11)$.

\section{Lesson \#3: "Money Is a Creature of the State"}

The ability of the government to conduct fiscal and monetary policy according to the principles of functional finance is made possible by the fact that "money is a creature of the state" (1947). The state has the power not only to tax, but to designate what will suffice to retire tax (and other) obligations, that is, what it will accept at its pay offices. By determining public receivability, the state can create a demand for otherwise worthless pieces of paper, leading to general acceptability. The state can issue this currency and use it to purchase goods and services from the private sector:

The modern state can make anything it chooses generally acceptable as money and thus establish its value quite apart from any connection, even of the most formal kind, with gold or backing of any kind. It is true that a simple declaration that such and such is money will not do, even if backed by the most convincing constitutional evidence of the state's absolute sovereignty. But if the state is willing to accept the proposed money in the payment of taxes and other obligations to itself the trick is done. Everyone who has obligations to the state will be willing to accept the pieces of paper with which he can settle the obligations, and all other people will be willing to accept those pieces of paper because they know that taxpayers, etc., will accept them in turn. On the other hand if the state should decline to accept some kind of money in payment of obligations to itself, it is difficult to believe that it would retain much of its general acceptability...What this means is that whatever may have been the history of gold, at the present time, in a normally well-working economy, money is a creature of the state. Its general acceptability, which is its all-important attribute, stands or falls by its acceptability by the state. (Lerner 1947, 313)

Thus, a variety of state powers--such as government's ability to tax, declare public receivability, create and destroy money, buy and sell bonds, and administer the prices it pays for goods and services purchased from the private sector--constitutes a menu of instruments with which full employment and stability of the value of the currency may be promoted.

\section{Lesson \#4: Taxing is not a funding operation}

Since money is a creature of the state and the government budget should be judged purely on its macroeconomic effects, decisions concerning taxation should be made only with regard to the economic effects in terms of the promotion of full employment, price stability, or other economic goals, and not ever "because the government needs to make money payments" (1943, p. 354): "(T)axes should never be imposed for the sake of the tax revenues" (1951, p. 131, original emphasis).

\section{Lesson \#5: Government Borrowing is not a funding operation.}

Likewise, for the same reasons as taxation, Lerner argued that "borrowing" is not a funding operation. Since it is not a funding operation, it is questionable whether we should even use the term "borrowing." Perhaps it would be best to simply refer to bond sales. Thus Lerner argued that "the government should borrow only if...the effects" of borrowing are desired (1943, p. 355). 


\section{Lesson \#6: The primary purpose of taxation is to influence the behavior of the public.}

If taxation is not a funding operation, then what is its purpose? The purpose of taxation, according to Lerner, is "its effect on the public of influencing their economic behavior" (1951, p. 131, original emphasis). First, through its power to determine public receivability, the government can create sellers who will offer goods and services for sale in exchange for the government currency. Thus, taxation, as mentioned above, endows otherwise worthless bits of paper with value. Another important way in which taxation affects the public's behavior is through its impact on spending. In the days when Lerner was much concerned with excess demand inflation, this was a major focus of his. But taxation can effect behavior in many other ways, and for Lerner this, and not funding government spending, is its primary function.

\section{Lesson \#7: The primary purpose of government bond sales is to regulate the overnight interest rate.}

As we have seen, for Lerner neither taxation nor government bond sales are funding operations. Taxation creates a demand for State money, and also can be used to fine-tune spending and other public behavior. What is the purpose of government bond sales if not to fund government spending? For Lerner, the primary purpose of bond sales is to manage reserves and thus the overnight rate of interest (inter-bank lending rate) in the face of government fiscal operations. The government should sell bonds, writes Lerner, "if otherwise the rate of interest would be too low" (1943, p. 355).

\section{Lesson \#8: Bond sales logically follow from, rather than precede, government spending.}

Since government need not "borrow" to finance its expenditure, and instead bond sales are a means of managing bank reserves and hitting some target rate of interest, then it follows that, logically speaking, bond sales follow from rather than precede government spending:

(T)he spending of money... out of deficits keeps on increasing the stock of money (and bank reserves) and this keeps on pushing down the rate of interest. Somehow the government must prevent the rate of interest from being pushed down by the additions to the stock of money coming from its own expenditures...There is an obvious way of doing this. The government can borrow back the money it is spending. (Lerner, 1951, pp. 10-11, original emphasis)

By selling bonds, government can drain the banking system of excess reserves created by its own deficit spending, and thus prevent the rate of interest from falling to 0 bid. Such a process clearly supports the view that, far from selling bonds in order to finance it expenditure, bond sales logically follow spending by the government.

\section{Lesson \#9: "Printing money" in and of itself has no impact on the economy whatsoever.}

For Lerner, there are six (or three pairs of) fiscal instruments of government: taxing and spending, buying and selling, and borrowing and lending. "Printing money" is not independent of these. Therefore, printing money, in and of itself, has no impact on the economy whatsoever. Suppose the government prints money and puts it in a rocket ship and blasts it to the moon. Will the printing of money have had any effect on the economy? Of course not:

(T)he creation of money has no effects on the economy as long as the printed money remains in the print shop. It is only when the money gets out into the economy that any effects come about. Money which is newly created and kept locked up might as ell never have been created.(Lerner, 1951, 132).

Only if the money printed is spent on goods and services or lent through issuing bonds, will there be some economic impact, but these impacts are already covered through the consideration of the six fiscal instruments: "The printing of money is not an instrument of policy. It is only a servant of these policies, just like printing stationery used in the various government departments" (Lerner, 1944, pp. 312-14): 
All the decisions of any importance are made when it is decided to apply the fiscal instruments...If any of the instruments involves the paying out of money..., the effects are just the same whether the money paid out was previously resting in the treasury or whether it had to be printed because there was not enough available in the treasury to permit them to be carried out on the scale that was considered necessary to prevent deflation. The use of the instrument should never be hampered just because there may not be enough money stock in the treasury at the moment. To sacrifice the prevention of deflation because of shortage of money which could be printed is no more sensible than to refrain from carrying out any other important government action because the necessary paper forms or stationery would have to be printed.(Lerner, 1951, p. 133).

\section{Lesson \#10: Without a full employment policy, society cannot benefit from labor-saving technological advance, that is, efficiency becomes inefficient. With a full employment policy, labor-saving technical advance becomes truly beneficial to society.}

Under conditions of continuous full employment, resources are scarce and so instituting a technical or organizational innovations that would free up some labor for other uses constitutes a welcome economizing of resources. But in an economy with persistent unemployment, what would have been efficient becomes inefficient:

When there is unemployment...it is not important or even useful to use less resources in any task... There is no point, for instance, in managing to carry out some task with less labor if there are unemployed workers available, because the workers set free would not be utilized for other tasks any more than the workers who are already unemployed. They would merely be added to the unemployed. Where there is unemployment, an increase in efficiency in any particular productive process does not result in any increase in the efficiency in the economy as a whole.(Lerner, 1951, p. 143)

Lerner does consider the possibility that instead of producing the same amount of output with a fewer number of workers, society could produce more output with the same amount of workers. Yet, as he rightly points out, if there is increased saving resulting from the increased income that would accompany the higher level of output, unless there is an exactly offsetting higher level of investment or government expenditure, the new higher level of output will not be sustainable, as all production will not be sold, and firms will cut back their production and lay off workers. In the absence of a full employment policy:

Economizing resources by the use of more efficient methods is like pouring water into a broken vessel with a large hole in it that is already holding as much as it can hold. No matter how much more is poured into it there will remain no more than at the beginning. The savings due to greater technical efficiency merely go to waste in further unemployment just as any additional water merely goes to waste through the hole.(Lerner, 1951, p. 144)

Neither is it the case that such technical advances are merely neutral; they may be harmful. First, rather than making more leisure possible, with labor-displacing technical advance "what we get is not the tranquillity of refraining from effort but the frustration of failing to find work. In ewvery socially significant sense the increase in efficiency brings not greater happiness but greater misery" (Lerner, 1951, p 144).

Second, labor-displacing technical advance may result in lower aggregate output and income. This can occur if the technical change leads to a redistribution of income from wages to profits, or from those with a higher marginal propensity to consume to those with a lower marginal propensity to consume. In such a case, aggregate spending will decline, reducing effective demand, and thus aggregate output and income (Lerner, 1951, pp. 144-45).

With a true full employment policy in place however, labor-displacing technical change is truly efficient, since the inceased efficiency will not result in unemployment. Thus, technical advance can be welcomed by society, as it is truly beneficial. 


\section{Lesson \#11: Without a full employment policy, a country must suffer over its trade balance. With a}

full employment policy, there is no need to worry about importing "too much" relative to exports.

In the absence of full employment guaranteed by functional finance, a country must worry about rising unemployment stemming from an increase in the value of imports over the value of exports. Thus, an excess of imports over exports is considered an "unfavorable balance of trade" and the reverse is considered a "favorable balance of trade." But Lerner looks at foreign trade as "the means by which we obtain for our own use goods that are manufactured abroad" (Lerner, 1951, p. 321):

The input of the foreign-trade industry consists of the effort involved in the manufacture of our exports...The output of the foreign-trade industry consists of the imports which it yields to us for our use. (Lerner, 1951, p. 321, original emphasis)

In other words, exports are a cost, and imports are a benefit. Thus, with a real commitment to full employment, an increase in a country's imports relative to its exports is an increase in its benefits. It is only without a full employment policy that this is undermined, as such a development will have a negative impact on aggregate demand, output, income, and employment. Countries therefore attempt to increase employment through promoting exports and restricting imports, i.e., by promoting costs and restricting benefits.

The idea that a country can cure unemployment only by developing an export surplus is completely baseless unless the society has developed a taboo against every other way of increasing the level of spending...Functional Finance dissolves any "imported unemployment." (Lerner, 1951, pp. 327, 332).

\section{Lesson \#12: Attempts to argue that the deficit and debt are not really as big as they look, or that if we measure them differently or keep a capital account they are not really that bad, are counter-productive.}

For Lerner, "deficit doves," by trying to placate concerns about government budget deficits and the national debt, actually do harm to their own position as "proponents of organized prosperity" (Lerner, 1951, p. 15):

A kind of timidity makes them shrink from saying anything that might shock the respectable upholders of traditional doctrine and tempts them to disguise the new doctrine so that it might be easily mistaken for the old. This does not help much, for they are soon found out, and it hinders them because, in endeavoring to make the new doctrine appear harmless in the eyes of the upholders of tradition, they often damage their case. Thus instead of saying that the size of the national debt is of no great concern...(and)...that the budget may have to be unbalanced and that this is insignificant when compared with the attainment of prosperity, it is proposed to disguise an unbalanced budget (and therefore the size of the national debt) by having an elaborate system of annual, cyclical, capital, and other special budgets.(Lerner, 1951, p. 15).

Even worse for Lerner are those who state they agree with the principles of functional finance but waffle in their support because they believe the public will not understand, and those who claim that functional finance seems reasonable but believe there must be something wrong with it that they are unable to see (Lerner, 1951, p. 16). The former tend to be 'intellectuals' who underestimate the public's ability to understand, while the latter tend to be members of the public who hold intellectual adherents of sound finance in unwarranted high esteem. Both tendencies result in stalling policies for prosperity. Lerner compares the situation to the fable of the emperor with no clothes, in which the people are too timid or fearful to speak out. When it comes to functional finance,

The scholars who understand it hesitate to speak out boldly for fear that the people will not understand. The people, who understand it quite easily, also fear to speak out while they wait for the scholars to speak out first. The difference between our present situation and that of the story is that it is not an emperor but the people who are periodically made to go naked and hungry and insecure and discontented-a ready prey to less timid organizers of discontent for the destruction of civilization. (Lerner, 1951, p. 16, original emphasis) 
Lesson \#13: When there is unemployment, jobs and money, not resources and goods, are scarce.

In a full employment economy, resources are scarce. Economizing is important, as resources can only be allocated to any use if they are removed from some other productive activity. In an economic system with unemployment, however, goods are not scarce, as more can be produced by employing the unemployed resources. But there are other kinds of scarcity in the economy suffering from unemployment:

What is scarce is money. The lack of money to spend on the goods is what keeps the unemployed resources from producing more goods. Work, moreover, instead of being a curse, is desired more than anything else because the alternative is not the enjoyment of leisure but the suffering of unemployment and deprivation. Of course, if people could get income without having to work they would not object too much (although their self-respect in feeling they are useful members of society who are earning their income is too easily underestimated). But it is only by finding work that they can obtain the necessary income they need. (Lerner, 1951, 147-48)

\section{Lesson \#14: Functional Finance is not a policy; it is a framework within which all sorts of policies may be conducted.}

There may be misconceptions that functional finance is equated with a particular policy, e.g., running a big deficit. Functional finance is rather a general approach within which a whole series of policies may be conducted. The actual policies which will be implemented will depend on the economic circumstances that exist at a particular time. Functional finance is an outlook that what matters are the effects of policies and not the policies themselves, which are mere means. Thus functional finance does not advocate big deficits under any and all circumstances, just as it does not view a balanced budget as inherently 'good' in and of itself, independently of its impact on the economy.

What functional finance advocates first and foremost is that policy be based on an understanding of the monetary and financial system in which we live, and not some idealized vision of some other system, or some system that may have existed at some other time. For example, if fiscal and monetary policy is formulated as if we were on a gold standard, we not only will sacrifice tremendous potential benefits, we may subject ourselves to grave danger. You cannot, and should not, run a fiat currency system by the logic of a metallic standard system.

\section{Lesson \#15: To achieve full employment, government spending may have to include direct job creation.}

Traditional fiscal and monetary policies may be ineffective in achieving full employment. Direct job creation in the form of public works may be necessary in order to attain and maintain full employment and price stability (1944, 315ff). Even public employment that produces no visible good or service is beneficial, in that it still creates jobs for the unemployed and increases aggregate output and income, with all their associated benefits. But there is no reason that public employment should ever have to be unproductive, since there are so many public and social services and activities that are not normally undertaken by the private sector and that benefit the economy and society in numerous ways (see, e.g., 1951, 90ff).

Public works can increase the productivity of the private sector. In addition, public employment is key to respecting individuals' desire not to relocate in order to find employment, which avoids disruption of family and community.

\section{Conclusion}

The work of Abba Lerner on functional finance and full employment contains lessons as relevant today as when they were first put forward some five decades ago. At a time when orthodox theory and policy offers little in the way of either explanation of the causes of crisis or cures in the form of effective policy approaches, it would do well to revisit these ideas and the ideas of other great thinkers of the past. Their work is of more than antiquarian interest; they contain valuable lessons that can inform current analysis and formulation of 
approaches to macroeconomic policy.

\section{References}

Lerner, Abba. 1941. "The Economic Steering Wheel." University of Kansas Review (June).

—. 1943. "Functional Finance and the Federal Debt." Social Research 10: 38-51.

—. 1944. The Economics of Control. New York: Macmillan.

—. 1947. "Money as a Creature of the State." American Economic Review 37.

—. 1951. The Economics of Employment. New York: McGraw Hill.

1969. "On Instrumental Analysis." In Economic Means and Social Ends: Essays in Political Economics edited by R. L. Heilbroner. Englewood Cliffs, N.J.: Prentice Hall. 